\title{
Metalloproteinase Inhibitor 2
}

National Cancer Institute

\section{Source}

National Cancer Institute. Metalloproteinase Inhibitor 2. NCI Thesaurus. Code C17542.

Metalloproteinase inhibitor 2 (220aa, $24 \mathrm{kDa}$ ) is encoded by the human TIMP2 gene.

This protein plays a role in metalloproteinase inhibition. 